\section{EVOLUTION FOR ALL}

\section{Understanding Evolution}

By Herbert H. Ross. (A Spectrum Book.) Pp. ix +175. (Englewood Cliffs, N.J., and London: Prentice-Hall, 1966.) $20 s$.

THIs book is a remarkably successful attempt to give an account of evolution from the possible modes of beginning of the universe down to the production of man and such extremely recent phenomena as industrial melanism, all done in 165 pages of text with numerous illustrations, yet very readable. The ten principal divisions of the book deal with: history of evolutionary thought; evolution of the universe; life's nature and origin; the progress of life; passage through time (including opportunism, survival and extinction); variation and natural selection; increase in the number of species; the geotectonic factor (influence of the major geological events on evolution); evolution of ecological communities; and progression of change (summary). The width of treatment is unusual and extends to constituent topics as well-it is pleasant to find an author who does not spend his whole space for speciation on geographical speciation-yet in those topics of evolution that I know something about the treatment is remarkably comprehensive and clear although condensed, and very up to date. It would be easy, no doubt, to disagree over some points of emphasis or details of fact or omission, but most of those I have noted seem to me trivial in comparison with the good points of the book. It should be looked at by anyone seeking a good (and cheap) text for students and for non-biologists.

\section{A. J. CAIN}

\section{OBITUARIES}

\section{Dr Douglas McClean}

Douglas MoCllan, bacteriologist in charge of the Vaccine Lymph Department of the Lister Institute of Preventive Medicine for twenty-five years, died in Oxford on July 10. He was born on May 13, 1896, in Constantinople, where his father was at the time medical superintendent at the British Seamen's Hospital. At the age of nine he came to England, where he was at school until he went to St. Thomas's Hospital in 1914. His medical training was interrupted by three years service as surgeon probationer in the Harwich Force of the Royal Navy, which left a permanent somewhat nautical stamp on him. He returned in 1919 to complete his training, and in 1924 took up the post of pathologist at Great Ormond Street Hospital for Sick Children.

Although he had a real interest in clinical problems he was irked by the inadequacy of current knowledge about the causation and especially the prevention of infective disease, and in 1928 he went to work under Dr (later Sir John) Ledingham at the Lister Institute at Chelsea. Here he was introduced to the study of viruses, especially vaccinia, and in 1930 he was appointed assistant bacteriologist in the Institute's serum department at Elstree. In producing vaccine lymph it was the practice to infect the skin of sheep with seed vaccine prepared in rabbit testicles, and McClean observed that uninfected testicular extracts had a remarkable capacity to enhance the diffusion of substances injected into the skin. His first paper on the phenomenon was published in 1930, and heralded a series of studies on the action of "spreading factor" and its possible role in microbial invasion, in fertilization and in therapeutics. He did not himself characterize the factor as a hyaluronidase, nor was he the first to demonstrate its production by bacteria, but his observation, which was contemporary with a similar independent observation by Duran-Reynals, opened up a new field of research and was a contribution to the recognition that bacterial toxins might be specific enzymes, which was first proved by M. G. Macfarlane and and B. C. J. G. Knight, also at the Lister Institute, in the case of the lecithinase of Clostridium perfringens. McClean became bacteriologist in charge of the vaccine lymph department in 1936, in which role he made a number of significant improvements in the production and stabilization of vaccine lymph, especially by devising a means of virtually eliminating contaminating bacteria by treatment with phenol.

Despite his critical yet enthusiastic approach to his scientific work, the execution of which he thoroughly enjoyed, he never wholly abandoned what might be called an amateur status, and refused to allow seience (or administration, which he did well) to exclude his other interests. He enjoyed his garden, his bees, and good conversation - especially accompanied by good wine, of which he was a connoisseur. He shared with his wife (a well known writer and illustrator of children's books) a circle of artistic friends. Finally, he was a firm advocate of socialist principles-and an equally firm upholder of civil liberties - and he found an outlet for an important part of his energies in promoting the work of the Association of Scientific Workers.

J. H. HUMPHREY

\section{University News:}

Massachusetts Institute of Technology

Professor Harry C. Gatos, at present both professor of electronic metallurgy in the Department of Metallurgy and Materials Science and professor of molecular engineering in the Department of Electrical Engineering, has been appointed associate director of the Center for Materials Science and Engineering.

Reading

DR P. G. HaLl, at present reader in geography at the London School of Economics and Political Science, has been appointed to the chair of geography in succession to Professor T. G. Miller, who has been appointed principal of the University College of Rhodesia.

\section{Appointments}

Sir Stanley Brown, chairman of the Central Electricity Generating Board, has been elected president of the Institution of Electrical Engineers for the session 1967 68. The chairmen of the three divisions of the institution have also been elected as follows: Dr E. EAstwood, director of research for English Electric, chairman of the Control and Automation Division; Mr J. H. H. MerRIMAN, senior director of engineering in the Post Office, London, chairman of the Electronics Division; MR F. C. Rippon, director of C. A. Parsons and Co., Ltd., Newcastle upon Tyne, chairman of the Power Division.

Admiral O. A. Quinillalt of Argentina has been elected chairman of the now Board of Governors of the International Atomic Energy Agency, and $\mathrm{Mr}$ N. Ivanchev, governor from Bulgaria, and Miss L. Rocsad, governor from Indonesia, have been elected vice-chairmen.

\section{Announcements}

THE Lalor Foundation makes annual awards to investigators for the study of basic phenomena and mechanisms in the field of reproductive physiology, and the 1968 programme of awards will give priority to applied seientific and clinical research on intra-uterine phonomena, uterine peristalsis in relation to implantation, early gestation and its control, clinical research on the physical sequelae of abortion, and the like. Further information about these awards can be obtained from the Director, Lalor Foundation, 4400 Lancaster Pike, Wilmington, Delaware. 